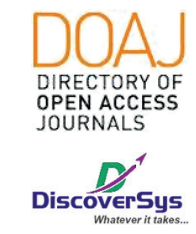

Published by DiscoverSys

\section{Metilasi DNA dalam Perkembangan Kanker Kolorektal}

\author{
Ni Made Pramita Widya Suksmarini, ${ }^{1}$ Ni Nyoman Ayu Dewi ${ }^{2 *}$ \\ I Wayan Juli Sumadi ${ }^{3}$
}

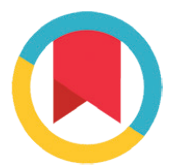

CrossMark

\title{
ABSTRACT
}

Colorectal cancer is a cancer occurs at the colon and rectum. Colorectal cancer is the second most cancer in developing countries with high mortality rate. For many years, genetic alterations have been traditionally seen as a driving force in the cancer initiation and progression. In recent years, however, epigenetic alterationis considered play an important role in cancer development. Epigenetic refers to heritable changes in the regulation of gene activity and expression that occurs without alteration of DNA sequence. Epigenetic controls gene expression via DNA methylation, histone modification and non-coding RNA. Methylation of DNA is, to date, the most studied of the epigenetic abnormalities in cancer. In this paper, we describe process of DNA methylation in normal and cancer cells, especially colorectal cancer. Knowledge and understanding of epigenetic mechanism is important for prevention and therapy of cancer.

Keywords: epigenetics, cancer, DNA methylation

Cite This Article:Suksmarini, N.M.P.W., Dewi, N.N.A., Sumadi, I.W.J. 2018. Metilasi DNA dalam Perkembangan Kanker Kolorektal. Intisari Sains Medis 9(2): 124-130. D0I: 10.1556/ism.v9i2.176

\section{ABSTRAK}

Kanker kolorektal adalah kanker yang terjadi pada kolon (usus besar) dan rektum. Kanker kolorektal menempati urutan kedua sebagai penyebab kanker di negara-negara berkembang dengan angka kematian yang tinggi. Selama ini perubahan genetik dipandang sebagai faktor paling penting dalam inisiasi dan progresivitas kanker. Namun beberapa tahun terakhir diketahui bahwa perubahan epigenetik juga memiliki peran yang sama pentingnya dengan perubahan genetik dalam perkembangan kanker. Perubahan epigenetik adalah perubahan dalam pengaturan aktivitas gen dan ekspresinya tanpa terjadinya perubahan urutan DNA. Perubahan epigenetik meliputi metilasi DNA, modifikasi histon, dan non-coding $R N A$. Diantara ketiga mekanisme ini, metilasi DNA adalah yang paling banyak dipelajari dalam hubungannya dengan perubahan epigenetik pada kanker. Dalam artikel ini dibahas mengenai proses metilasi DNA pada sel normal dan sel kanker, khususnya kanker kolorektal. Pengetahuan dan pemahaman mengenai mekanisme epigenetik sangat diperlukan untuk kepentingan pencegahan maupun pengobatan kanker.
'Program Studi Pendidikan Dokter, Fakultas Kedokteran Universitas Udayana

${ }^{2}$ Bagian Biokimia Fakultas Kedokteran Universitas Udayana

${ }^{3}$ Bagian Patologi Anatomi, Fakultas Kedokteran, Universitas Udayana-RSUP Sanglah

${ }^{*}$ Correspondence to: Ni Nyoman Ayu Dewi, Bagian Biokimia Fakultas Kedokteran Universitas Udayana ayu.dewi@unud.ac.id

Received: 2018-02-27

Accepted: 2018-03-5

Published: 2018-05-1
Kata kunci: epigenetik, kanker, metilasi DNA

Cite Pasal Ini: Suksmarini, N.M.P.W., Dewi, N.N.A., Sumadi, I.W.J. 2018. Metilasi DNA dalam Perkembangan Kanker Kolorektal. Intisari Sains Medis 9(2): 124-130. DOI: 10.1556/ism.v9i2.176

\section{PENDAHULUAN}

Perubahan epigenetik diketahui berperan penting pada perkembangan kanker. Modifikasi epigenetik meliputi metilasi DNA dan modifikasi protein histon. ${ }^{1}$ Perubahan pola metilasi pada promoter atau ekson pertama dari suatu gen dapat meniru efek mutasi berbagai tumor suppressor genes (TSGs) atau protoonkogen. Metilasi DNA adalah proses penambahan gugus metil pada DNA; dalam proses ini terjadi modifikasi nukleotida kovalen dalam genom manusia yaitu sitosin dan juga guanin, yang merupakan dinukleotida CpG. Karsinogenesis juga dapat disebabkan oleh penyimpangan dalam metilasi DNA yang mencakup hipermetilasi dan hipometilasi promoter atau ekson pertama dari gen yang berhubungan dengan kanker.

Kanker merupakan suatu perkembangan tidak normal dari suatu sel tubuh yaitu tidak terkendalinya pembelahan sel dan dapat menginvasi jaringan lain melalui pembuluh darah dan limfa dalam suatu proses yang disebut metastasis. Tingkat prevalensi kejadian kanker meningkat dengan sangat pesat; diperkirakan pada tahun 2030, sekitar 21,6 juta kasus baru dan 13,0 juta kematian akan terjadi. ${ }^{2}$ penyebab dari tujuh kematian di dunia, salah satunya kanker kolorektal. Saat ini kanker berkontribusi menjadi salah satu 
Kanker kolorektal adalah kanker yang terjadi pada kolon (usus besar) atau rektum. American Cancer Society menyebutkan bahwa kanker kolorektal menempati urutan ketiga jenis kanker terbanyak yang diderita dengan resiko terjadi pada satu orang di antara dua puluh orang. ${ }^{3}$ Kanker ini juga menempati urutan kedua sebagai penyebab kanker di negara-negara berkembang dengan satu juta kasus baru dan 500.000 kematian di seluruh dunia setiap tahunnya. ${ }^{4}$ Angka yang cukup tinggi ini terjadi sebagai akibat dari gaya hidup dan kebiasaan masyarakat yang tidak sehat seperti tidak mengatur pola makan, malas berolahraga dan merokok, yang juga bersamaan dengan tingkat kelahiran yang cukup tinggi khususnya di negara-negara berkembang.

Perubahan epigenetik merupakan mekanisme mengubah ekspresi gen tanpa mengubah urutan DNA. Dari mekanisme perubahan epigenetik yang ada, metilasi DNA sangat berpotensi sebagai biomarker untuk deteksi dini, prognosis dan memperkirakan akibat dari kemoterapi pada pasien kanker. Jumlah metilasi DNA meningkat seiring dengan penuaan dan dipercepat dengan adanya peradangan pada kolon. ${ }^{5} \mathrm{C} p \mathrm{G}$ island methylator phenotype (CIMP) merupakan molekul utama pada mekanisme karsinogenesis kanker kolorektal, ${ }^{6}$ dan berhubungan dengan perkembangan kanker ini pada $20 \%$ kasus yang terjadi. ${ }^{7}$ Mekanisme CIMP pada perkembangan kanker kolorektal masih belum diketahui dengan pasti, namun diketahui kanker ini dapat dikelompokkan berdasarkan jumlah metilasi dari marker CIMP. Perubahan-perubahan yang terjadi menjadi kunci utama dalam mendiagnosis dan mengobati kanker kolorektal.

\section{Metilasi DNA}

Pada tahun 1940 an, Conrad Waddington pertama kali memperkenalkan istilah epigenetik yang menjelaskan interaksi gen dengan lingkungan sehingga mempengaruhi perkembangan dan embriologi. Pewarisan epigenetik saat ini didefinisikan sebagai perubahan ekspresi gen tanpa mengubah urutan DNA yang diwariskan selama pembelahan sel. ${ }^{8}$ Secara garis besarnya epigenetik meliputi metilasi DNA, modifikasi histon, dan non-coding RNA. Diantara tiga mekanisme ini, metilasi DNA adalah yang paling banyak dipelajari.

Metilasi DNA adalah penambahan gugus metil (-CH3) dari kelompoks-adenosylmethionine (SAM) ke posisi $5^{\prime}$ sitosin dalam urutan gen sehingga membentuk 5-methylcytosine $(5 \mathrm{mC})$. Proses ini dikatalisis oleh enzim DNA methyltransferase (DNMTs). ${ }^{9}$ Metilasi DNA dapat mengubah aktivitas ekspresi gen tanpa mengubah urutan gen dan bersifat diturunkan. Lokasi terjadinya metilasi disebut dengan CpG (5'-C-phosphate-G-3') site.
Terdapat sekitar 5-10\% CPG site yang tersebar pada gen manusia dan mengalami metilasi sebanyak $70-80 \%$ di luar $C p G$ island. $C p G$ island adalah daerah dengan paling sedikit 200 pasangan basa dengan persentase guanin dan sitosin lebih dari 50\%; umumnya daerah ini tidak termetilasi dan biasanya terletak pada promoter gen. ${ }^{9}$

\section{Metilasi DNA pada Perkembangan Sel Normal}

Metilasi DNA merupakan proses memodifikasi nukleotida kovalen dalam genom manusia yaitu sitosin dan juga guanin dalam urutan DNA, yang merupakan dinukleotida CpG. CpG island di daerah promoter gen biasanya tidak termetilasi, sedangkan $C p G$ site yang sporadik biasanya termetilasi. Namun pada proses penuaan atau karsinogenesis, akan terbentuk pola hipometilasi global dan daerah promoter menjadi hipermetilasi. ${ }^{6}$ Sitosin dimetilasi di posisi C-5 (cytosine-5) oleh DNA methyltransferase (DNMTs) dengan donor universal metil s-adenosyl-L-methionine (SAM). 5-methylcytosines mencakup $1 \%$ dari total basa DNA dalam genom manusia dan mempengaruhi 70-80\% lokasi CpG pada sel somatik manusia. Ketika sitosin tidak bermetilasi mengalami deaminasi menjadi urasil, sistem perbaikan DNA (DNA repair) dapat mengembalikan urutan aslinya menjadi sitosin kembali. Namun, sistem perbaikan DNA tidak mengenali timin yang dihasilkan dari deaminasi 5-methylcytosine (Gambar 1). Oleh karena itu, deaminasi spontan 5-methylcytosine menyebabkan mutasi transisi $\mathrm{C}$ ke T pada genom. ${ }^{8}$

A Deaminasi
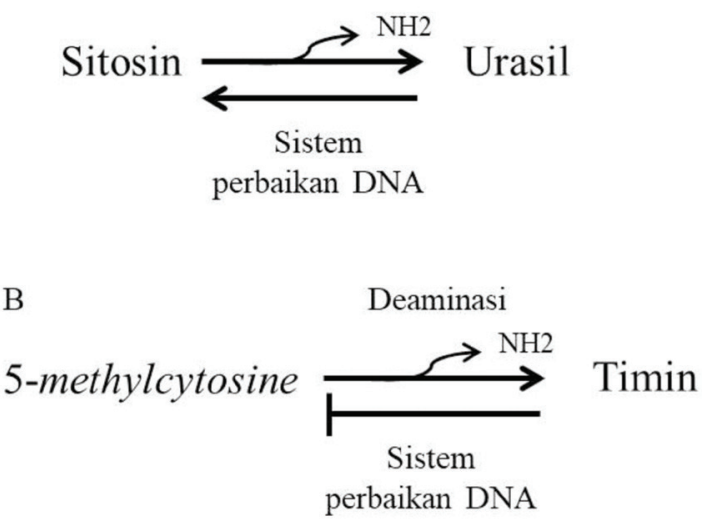

Gambar 1 Deaminasi sitosin. Deaminasi dari sitosin yang tidak mengalami metilasi menjadi urasil dapat diperbaiki oleh sistem perbaikan DNA menjadi sitosin kembali (A), sedangkan timin yang dihasilkan dari deaminasi 5-methylcytosine tidak dapat diperbaiki (B) 
Sebagian dari dinukleotida CpG yang ada di genom berada di $C p G$ island yang merupakan daerah kaya $C P G$ yang memiliki kepadatan relatif tinggi. Daerah ini terutama terletak di ujung 5 ' dari sebagian besar gen manusia dan biasanya tidak termetilasi. Analisis komputasi menunjukkan bahwa setidaknya ada 29.000 CpG island pada gen manusia. ${ }^{8}$ Berbeda dengan $C p G$ island, $C p G$ site yang terletak di luar daerah promoter berada dalam keadaan termetilasi.

Proses nonaktivasi transkripsi gen oleh metilasi DNA melalui dua jalur berbeda: ${ }^{8}$

1) Methyl-CpGs menghambat faktor transkripsi secara langsung dengan cara berikatan pada rangkaian faktor transkripsi. Walaupun pengaturan dari mekanisme in vivo sangatlah jarang, beberapa faktor transkripsi seperti Ets-1 dan faktor elemen CTCF tidak mampu mengikat DNA apabila sitosin tersebut termetilasi.

2) Metilasi DNA dapat mengambil protein yang mengikat CpGs bermetilasi dan kemudian menghambat transkripsi dengan mengubah struktur kromatin.

Beberapa komponen yang terlibat dalam mekanisme epigenetik yaitu:

\section{A) DNA Methyltransferase (DNMTs)}

DNMTs merupakan enzim yang berperan dalam membentuk dan mempertahankan sel dengan DNA bermetilasi dan dikenal adanya tiga katalis aktif DNMT yaitu DNMT1, DNMT3A, dan DNMT3B. DNMT1 berperan sebagai methyltransferase yang mempertahankan pola metilasi pada $\mathrm{DNA}^{6}$ sedangkan, DNMT3A dan DNMT3B berperan menginisiasi metilasi de novo dengan membentuk pola metilasi. Selain DNMT1, DNMT3A, dan DNMT3B, dikenal juga DNMT2 yang fungsinya masih belum jelas diketahui, namun kekuatannya mengikat DNA diperkirakan berperan dalam menentukan urutan spesifik gen. ${ }^{10}$

B) Methyl-CpG-binding proteins (MBPs)

Dari dua belas jenis MBP yang telah teridentifikasi, MECP2, MBD1, MBD2, dan MBD3 adalah jenis yang sering diteliti. Selain MBD3, sebelas jenis MBP ini secara selektif mengikat sisi CpG bermetilasi. MECP2 menghambat ekspresi gen dengan mengikathistone deacetylase dan histone lysine methyltransferase. Pada sel kanker, protein MBD berhubungan dengan perubahan metilasi tumor suppressor gen (TSGs) dan menghubungkan antara mekanisme metilasi DNA dan gene silencing. ${ }^{11}$

\section{C) Histone modification enzymes}

Histone modification enzymes terdiri dari histone deacetylase (HDAC), histone acetylase (HAT), dan histone methyltransferase (HMT) yang bertanggungjawab pada modifikasi histon dan chromatin remodeling. ${ }^{12}$ Ujung amino dari histon dapat mengikat gugus asetil, fosfor, metil atau ubiquitin, dan modifikasi yang terjadi menunjukkan aktivitas gen. Asetilasi lisin histon didistribusikan oleh histon asetiltransferase yang secara umum berkaitan dengan aktivasi transkripsi. Beberapa ko-aktivator transkripsi, seperti p300/CBP, berperan seperti histon asetiltransferase. Fungsi dari metilasi histon bergantung pada jenis residu (lisin atau arginin) dan lokasi spesifiknya, contohnya metilasi lisin nomor empat pada histon $\mathrm{H} 3$ berhubungan dengan transkripsi, dimana metilasi lisin nomor sembilan pada ujung histon yang sama berhubungan dengan berkurangnya transkripsi.

D) ATP-dependent remodeling complexes

Enzim ini dapat mengubah struktur kromatin dengan mengganggu atau menggerakkan nukleosom. Hal ini meningkatkan aksesibilitas nukleosom DNA yang sangat diperlukan dalam beberapa tahapan transkripsi. ${ }^{8}$

Umumnya CpG island tidak bermetilasi pada jaringan normal kecuali pada beberapa kasus berikut: imprinted genes, $x$-chromosome genes in women, germ-line specific genes dan tissue specific genes. ${ }^{8}$

\section{a. Genomic Imprinting}

Penelitian perdana tentang pengidentifikasian gen imprinting adalah gen insulin-like growth factor 2 (Igf2) pada tikus, dan kemudian gen sejenis ini dapat diidentifikasi pada manusia. ${ }^{8}$ Berbeda dengan genom manusia yang merupakan pengekspresian dari alel ayah dan ibu, imprinted gen bersifat haploid dan memiliki pola yang bergantung pada alel yang pertama kali terbentuk. Mekanisme genomic imprinting sangatlah kompleks dan belum dapat dipahami sepenuhnya, tetapi disebutkan bahwa metilasi DNA berperan dalam mekanisme ini. Beberapa imprinted gene berperan penting dalam mengatur pertumbuhan dan perkembangan serta menyeimbangkan kecepatan pertumbuhan janin. Pada tahun 1989 diperkenalkan teori "Parent-offspring Conflict Model", yaitu sifat dari gen ayah yang mengoptimalkan kebugaran reproduksi keturunannya dengan mempromosikan pertumbuhan mereka, dan gen ibu yang akan mendapat keuntungan dari melestarikan sumber dayanya sendiri dan 
mendistribusikan sumber daya ibu yang terbatas secara setara untuk semua keturunan saat ini dan masa depan. Hal ini ditunjukkan oleh faktor pertumbuhan spesifik janin yang diekspresikan secara paternal, yang merangsang pertumbuhan, dan Igf2r yang diekspresikan secara maternal yang menetralkan Igf2 dengan mentransmisikannya ke dalam lisosom untuk didegradasi, sehingga menghambat pertumbuhan embrio. Beberapa penyakit genetik berkaitan dengan adanya cacat pada imprinted gen seperti Beckwith-Wiedermann, Prader-Willi dan Angelman Syndrome, dan Beckwith Wiederman Syndrome berhubungan erat dengan timbulnya tumor embrional yaitu Wilm's tumor dan adrenokortikal karsinoma. ${ }^{8}$

b. X-chromosomal Inactivation

Merupakan sebuah mekanisme yang menyeimbangkan ekspresi $x$-linked gene antara lakilaki (satu kromosom X) dan perempuan (dua kromosom X). X-chromosome inactivation bersifat monoalel, dan satu dari kromosom $\mathrm{X}$ pada perempuan menjadi inaktif di awal proses perkembangan akibat dari transkripsi gen XIST (X-inactive specific transcript), sebuah transkrip noncoding yang menginduksi perubahan kromatin $^{8}$ sehingga secara sitologi kromosom ini tampak seperti Barr body pada nukleus. Mekanisme inaktivasi ini memerlukan bantuan metilasi DNA dalam hipermetilasi CPG island.

c. Tissue specific genes

Sejak lebih dari dua puluh lima tahun yang lalu, metilasi DNA dikenal sebagai pengatur ekspresi gen pada jaringan tubuh. SERPINB5 (maspin) adalah gen yang pertama kali diidentifikasi terkait hal ini. ${ }^{8}$ Ekspresi gen ini terbatas pada beberapa jenis sel seperti : kulit, saluran napas dan rongga mulut. Sel-sel ini membawa promoter SERPINB5 yang termetilasi dengan hipoasetilasi histon dan struktur kromatin yang sulit diakses.

d. Germ line specific genes

Gen ini tidak dapat diekspresikan pada jaringan somatik yang normal, tetapi pada berbagai jenis tumor. MAGE1 (melanoma-associated antigen) adalah gen yang pertama kali diidentifikasi dan kini sekitar sembilan puluh jenis gen telah diidentifikasi seperti MAGE, GAGE, PAGE, dan XAGE. ${ }^{8}$ Penelitian membuktikan bahwa pada jaringan somatik normal, gen memiliki jumlah metilasi DNA yang tinggi sedangkan ditemukan banyak DNA tidak bermetilasi pada sel kanker.

\section{Metilasi DNA pada Perkembangan Sel Kanker}

Proses metilasi DNA pada perkembangan normal akan mengalami gangguan selama proses tumorigenesis. Penyimpangan metilasi DNA ini berupa hipermetilasi DNA pada promoter $(C P G$ island) dan hipometilasi DNA pada CpG site di luar promoter DNA. Kasus ini pertama kali dibuktikan pada tahun 1983, dengan ditemukannya CpG yang kehilangan DNA bermetilasi pada sel kanker. ${ }^{8}$ Sejak saat itu, mulai dilakukan penelitian-penelitian yang membahas tentang hubungan metilasi DNA pada perkembangan kanker. Hipermetilasi pada $C p G$ island mengacu pada penambahan metilasi DNA yang normalnya tidak termetilasi. Proses terhambatnya transkripsi oleh karena metilasi pada promoter DNA menyebabkan gen tersebut tidak terekspresi. Metilasi pada promoter tumor suppressor genes (TSGs) menyebabkan tidak terjadinya ekspresi gen sebagai penekan pertumbuhan sel yang terlalu cepat, sehingga dapat mendukung perkembangan sel kanker. 9

\section{Kanker Kolorektal}

Perkembangan sel kanker melalui proses yang cukup rumit. Setiap individu mempertahankan homeostasis dalam dirinya dengan menyeimbangkan antara jumlah sel yang berproliferasi dan sel yang mengalami kematian. Ketika proses homeostasis ini terganggu, baik disebabkan oleh peningkatan kecepatan proliferasi sel atau pengurangan jumlah sel yang mati, maka akan muncul neoplasma pada jaringan tersebut yang kemudian berkembang menjadi tumor. Perubahan ini terjadi akibat dari: 1) Aktivasi proto-onkogen, yang menyumbangkan gen secara konstitutif aktif atau aktif di bawah kondisi bukan tipe gen asing, 2) inaktivasi tumor suppressor genes (TSGs), sehingga menghambat aktivitas gen, 3) aktivitas repair genes, yang menjaga perubahan genetik seminimal mungkin. ${ }^{8}$

Analisis gen yang membahas penyimpangan struktural dan numerik kromosom, telah lama menyatakan bahwa kanker pada dasarnya adalah penyakit genetik. Penelitian-penelitian terakhir telah banyak membuktikan bahwa modifikasi epigenetik berperan penting dalam perkembangan sel kanker. Akumulasi dari mutasi gen dan perubahan epigenetik dapat menginisiasi benign adenoma menjadi malignant adenocarcinoma. Perkembangan kanker kolorektal sangatlah perlahan, bahkan sampai sepuluh tahunan. Umumnya kanker ini berawal dari polip yang muncul pada jaringan epitel kolon atau rektum, dapat bersifat jinak (contoh: hyperplastic polyp), semi-ganas (contoh: tubular adenoma), atau ganas (contoh: colorectal adenocarcinoma). Diperkirakan sekitar 20\% pasien memiliki riwayat keluarga penderita kanker kolorektal, dan juga sindrom genetik meningkatkan resiko terjadinya kanker kolorektal, contohnya pada Hereditary Nonpolyposis colorectal cancer (HNPCC atau Lynch syndrome) sebanyak 3\% serta 
pada Gardner syndrome dan Familial Adenomatous polyposis (FAP) sebanyak $1 \%$ pasien menderita kanker ini. Namun, mayoritas kasus kanker kolorektal lebih disebabkan oleh faktor lingkungan dibandingkan faktor genetik. ${ }^{13}$ Beberapa faktor lingkungan yang mempengaruhi timbulnya kanker ini adalah makanan, gaya hidup, mutagen dan juga inflamasi yang terjadi akibat dari parasit pada usus. Mekanisme patogenesis dari kanker kolorektal masih terus diteliti. Diketahui bahwa kanker ini merupakan akumulasi dari perubahan genetik dan epigenetik pada membran mukosa usus normal yang membentuk polip adenomatosa menjadi adenokarsinoma. ${ }^{14}$

Modifikasi epigenetik sangat berperan dalam patogenesis kanker kolorektal. Peran epigenetik pada epigenome sel kanker kolorektal yaitu modifikasi post translasi histon, asetilasi histon primer dan metilasi yang mengatur ekspresi dari onkogen dan tumor suppressor genes (TSGs). Dari mekanisme epigenetik yang ada, antara lain: nucleosomal occupancy dan remodeling chromatin looping serta noncoding RNA, metilasi DNA pada sitosin di dinukleotida CpG dan modifikasi posttranslasi protein histon yang membentuk DNA menjadi kromatin merupakan mekanisme yang berperan penting dalam proses perkembangan kanker kolorektal. ${ }^{15}$

\section{Hipermetilasi DNA pada Perkembangan Sel Kanker Kolorektal}

Salah satu petunjuk adanya proses perkembangan epigenetik kanker kolorektal adalah metilasi bialel promoter $C p G$ island pada mismatch repair gene MLH1. Perubahan epigenetik ditemukan pada lesi pre-kanker dan jaringan sekitar pada kanker kolorektal. ${ }^{6}$ Gen pengatur pertumbuhan ditemukan tidak aktif secara epigenetik pada mukosa kolon manusia dewasa, yang dapat meningkatkan resiko kanker dengan pertambahan usia. Metilasi ASC/ TMS1 ditemukan pada tahap akhir kanker kolorektal. ${ }^{16}$ Kanker dapat diklasifikasikan berdasarkan morfologi mikroskopik dan imunohistokimia. Pada tahun 1990 Fearon et al. menyatakan bahwa mayoritas kanker kolorektal berawal dari adenoma dan akumulasi dari mutasi gen selama karsinogenesis. Kanker kolorektal memiliki kadar DNA microsatellite instability (MSI-H) yang tinggi, CpG island methylator phenotype yang tinggi (CIMPhigh), dan mutasi $\mathrm{BRAF}^{5}$ CpG island methylator phenotype (CIMP) merupakan molekul utama pada mekanisme karsinogenesis kanker kolorektal ${ }^{6}$ serta suatu biomarker untuk mengklasifikasikan subgrup dari kanker kolorektal dan digunakan dalam penelitian terapi. Marker CIMP yang sering digunakan dalam penelitian adalah MLH1, p16, MINT1, MINT2, dan MINT31. ${ }^{17}$ CIMP pada kanker kolorektal berhubungan dengan usia, jenis kelamin, riwayat kanker pada keluarga, lokasi kanker pada kolon, diferensiasi sel musinus, lesi pada prekursor spesifik (contoh: serrated adenomas), merokok, MSI, BRAF, dan mutasi KRAS. ${ }^{18}$

Mekanisme CIMP pada perkembangan kanker kolorektal masih belum diketahui dengan pasti, namun diketahui kanker ini dapat dikelompokkan berdasarkan jumlah metilasi dari marker CIMP. Kanker kolorektal dapat diklasifikasikan berdasarkan jumlah CIMP, antara lain: 1) Kanker kolorektal CIMP tinggi, memiliki jumlah hipermetilasi DNA yang tinggi dan kecepatan yang tinggi dari mutasi BRAF (61\%); 2) Kanker kolorektal CIMP rendah, berhubungan dengan tingkat mutasi KRAS (45\%); 3) Kanker kolorektal tanpa CIMP, dapat dibagi menjadi dua kelompok berbeda yaitu berdasarkan mutan TP53 dan lokasi dari tumor. Namun beberapa studi menyebutkan bahwa hipermetilasi DNA atau peningkatan CIMP hanya berdampak kecil dalam proses perkembangan kanker kolorektal. ${ }^{19}$

Proses hipermetilasi DNA menginduksi transcriptional silencing dari tumor suppressor genes (TSGs) pada kolon normal dan neoplasia kolorektal. Penyimpangan metilasi DNA terjadi pada $C p G$ dinucleotides baik pada CPG islands di daerah promoter ataupun pada $C p G$ sites yang tersebar pada gene body. Pada sel normal, 5' promoter $C p G$ islands umumnya tidak termetilasi, sedangkan $C p G$ sites pada gene body umumnya dalam keadaan termetilasi. Susunan ini memberikan kemudahan akses bagi faktor transkripsi, seperti: TF-1, TF-2, TF-3 dan RNA polymerase II (RNA pol II) untuk mengikat promoter gen dan memfasilitasi ekspresi gen. Padaneoplasia kolorektal, DNMT berasosiasi dengan HDAC dan methyl binding proteins (MBP) mengkatalisis transfer dari kelompok metil ke sitosin padaCp $G$ sites, menghasilkan hipermetilasi yang menginduksi transcriptional silencing dari tumor suppressor genes, yang menggambarkan CIMP. Terjadinya hipermetilasi pada $C p G$ islands dan hipometilasi pada $C p G$ sites pada gene body menyebabkan hilangnya imprinting genes, aktivasi endoparasitic sequences, dan chromosomal instability pada sel kanker kolorektal. ${ }^{20}$

\section{Hipometilasi DNA pada Perkembangan Sel Kanker Kolorektal}

Penemuan pertama tentang hipometilasi global kanker kolorektal dipublikasikan pada tahun 1983 oleh Feinberg et al. Hipometilasi dari promoter 
CDH3 (P-cadherin) ditemukan pada aberrant crypt foci (ACF) dan kanker kolorektal dengan akumulasi hipometilasi $\mathrm{CDH} 3$ pada jaringan di sekitar epitel kolon. Hipometilasi pada daerah promoter berhubungan dengan induksi ekspresi $\mathrm{CDH} 3$ pada kanker kolorektal. ${ }^{21}$

Contoh hubungan pentingnya peran hipometilasi DNA pada kanker kolorektal adalah LINE-1. LINE-1 atau L1 retrotransposons mencakup sekitar $17 \%$ dari genom manusia dan kondisi metilasinya merupakan indikator dari tingkat metilasi DNA. Pada sel normal, $C p G$ site dengan LINE-1 pada elemen repetitif DNA dalam keadaan termetilasi yang berperan sebagai suppresi dari aktivitas transposon untuk menjaga keseimbangan homeostasis. ${ }^{22}$ Namun pada tumorigenesis, $C p G$ site ini dalam keadaan tidak termetilasi sehingga terjadi akumulasi hipometilasi yang merupakan $75-80 \%$ proses awal terbentuknya kanker kolorektal. ${ }^{23}$

Hipometilasi DNA juga terjadi pada urutan DNA yang repetitif dan pada daerah promoter miRNA pada kasus neoplasia kolorektal dibandingkan dengan sel kolon normal. Proto-oncogenes dan oncogenic miRNA tidak terekspresikan pada sel kolon normal. Ekspresi dari onkogen tersebut dihambat oleh hipermetilasi promoter CPG sites pada susunan berulang LINE-1 dan Alu. Tetapi, pada neoplasia kolorektal, urutan berulang LINE-1 dan Alu mengalami hipometilasi, dan mengaktifkan proto-oncogenes dan oncogenic miRNAs sehingga terjadi chromosomal instability. ${ }^{20}$

\section{KESIMPULAN}

Metilasi DNA adalah penambahan gugus metil (-CH3) dari kelompok s-adenosylmethionine (SAM) ke posisi $5^{\prime}$ sitosin dalam urutan gen sehingga membentuk 5-methylcytosine (5mC) dengan bantuan enzim DNA methyltransferase (DNMTs). Beberapa komponen yang terlibat dalam mekanisme metilasi DNA yaitu: DNA Methyltransferase (DNMTs), Methyl-CpG-binding proteins (MBPs), Histone modification enzymes, dan ATP-dependent remodeling complexes. Pada sel kolon normal, $C p G$ island di daerah promoter gen biasanya tidak termetilasi, sedangkan $C p G$ site yang sporadik biasanya termetilasi. Namun pada proses karsinogenesis kanker kolorektal terjadi penyimpangan metilasi DNA berupa hipermetilasi DNA pada promoter $C p G$ island dan hipometilasi DNA pada $C p G$ site di luar promoter DNA. Untuk dapat mencari alternatif terapi penanganan kanker kolorektal, penelitian yang dilakukan tidak hanya di tingkat DNA, namun juga pada tingkat kromatin sehingga dapat mencegah terjadinya metastasis ketika penyimpangan metilasi DNA pada sel kolon telah terdiagnosis.

\section{CONFLICT OF INTEREST}

Penulis menyatakan tidak ada conflict of interest.

\section{DAFTAR PUSTAKA}

1. Luczak, MW. and Jagodzinski, PP. 2006. The role of DNA methylation in cancer development. Folia Histochemica et Cytobiologica, 44, 143-154.

2. American Cancer Society. 2017. Cancer Facts \& Figures 2017.

3. Kopetz, S., Chang, GJ., Overman, MJ., Eng, C., Sargent, DJ., Larson, DW., Grothey, A., Vauthey, JN., Nagorney, DM., and McWilliams, RR. 2009. Improved survival in metastatic colorectal cancer is associated with adoption of hepatic resection and improved chemotherapy. J. Clin. Oncol. 27, 3677-3683.

4. Gray, R., Barnwell, J. and McConkey, C. 2007. Adjuvant chemotherapy versus observation in patients with colorectal cancer: a randomised study. Lancet, $370: 2020-2029$.

5. Boland, CR. dan Goel, A. 2010. Microsatellite instability in colorectal cancer. Gastroenterology, 138:2073-2087.

6. Guo, M. and Jia, Y. 2013. Epigenetic changes in colorectal cancer. Chin J Cancer, 32, 21-30.

7. Ouchi, K., Takahashi, S., Yamada, Y., Tsuji, S., Tatsuno, K., Takahashi, H., Takahashi, N., Takahashi, M., Shimodaira, H., Aburatani, H., and Ishioka, C. 2015. DNA methylation status as a biomarker of anti-epidermal growth factor receptor treatment for metastatic colorectal cancer. Cancer Sci, 106, 1722-1729.

8. Lind, GE. 2005. "DNA methylation in cancer development" (tesis). Oslo: University of Oslo.

9. Fidianingsih, I. 2013. Metilasi CpG island gen DAPK pada leukemia limfoblastik akut. JKKI, 5, 59-68.

10. Chen, ZX., Mann, JR., and Hsieh, CL. 2005. Physical and functional interactions between the human Dnmt3l protein and members of the de novo methyltransferase family. J Cell Biochem, 95:902-917.

11. Ballestar, E. and Esteller, M. 2005. Methyl-CpG-binding proteins in cancer: blaming the DNA methylation messenger. Biochem Cell Biol, 83: 374-384.

12. Mai, A. 2007. The therapeutic uses of chromatinmodifying agents. Expert Opin Ther Targets, 11:835-851.

13. Rustgi, AK. 2007. The genetics of hereditary colon cancer. Genes Dev., 21, 2525-2538.

14. Feagins, LA., Souza, RF., and Spechler, SJ. 2009. Carcinogenesis in IBD: Potential targets for the prevention of colorectal cancer. Nat. Rev. Gastroenterol. Hepatol.,6, 297-305.

15. Van Engeland, M., Derks, S., Smits, KM., Meijer, GA., and Herman, JG. 2011. Colorectal cancer epigenetics: Complex simplicity. J. Clin. Oncol.,29, 1382-1391.

16. Zhang W, Glockner SC, and Guo M. 2008. Epigenetic inactivation of the canonical Wnt antagonist SRY-box containing gene 17 in colorectal cancer. Cancer Res, 68:2764-2772.

17. Kim, MS., Lee, J. and Sidransky, D. 2010. DNA methylation markers in colorectal cancer. Cancer Metastasis Rev, 29: 181-206.

18. Jover, R., Nguyen, TP., Perez-Carbonell, L., Zapater, P., Paya, A., Alenda, C., Rojas, E., Cubiella, J., Balaguer, F. and Morillas, JD. 2011. 5-Fluorouracil adjuvant chemotherapy does not increase survival in patients with CpG island methylator phenotype colorectal cancer. Gastroenterology, 140, 1174-1181.

19. Olaru, AV., Cheng, Y., Agarwal, R., Yang, J., David, S., Abraham, JM., Yu, W., Kwon, JH., Lazarev, M. and Brant, SR. 2012. Unique patterns of $\mathrm{CpG}$ island methylation in inflammatory bowel disease-associated colorectal cancers. Inflamm. Bowel Dis., 18, 641-648. 
20. Goel, A., Xicola, RM. and Nguyen, TP. 2010. Aberrant DNA methylation in hereditary nonpolyposis colorectal cancer without mismatch repair deficiency. Gastroenterology, 138:1854-1862.

21. Hibi, K., Goto, T., Mizukami. H., Kitamura, Y., Sakuraba, K., Sakata, M., Saito, M., Ishibashi, K., Kigawa, G., Nemoto, H. and Sanada, Y. 2009. Demethylation of the CDH3 gene is frequently detected in advanced colorectal cancer. Anticancer Res, 29:2215-2217.

22. Estecio, MR., Gharibyan, V., Shen, L., Ibrahim, AE., Doshi, K., He, R., Jelinek, J., Yang, AS., Yan, PS., Huang, TH., Tajara, EH. and Issa, JP. 2007. LINE-1 hypomethylation in cancer is highly variable and inversely correlated with microsatellite instability. PLoS One, 2, e399.
23. Ahn, JB., Chung, WB., Maeda, O., Shin, SJ., Kim, HS., Chung, HC., Kim, NK. and Issa, JP. 2011. DNA methylation predicts recurrence from resected stage III proximal colon cancer. Cancer, 117, 1847-1854.

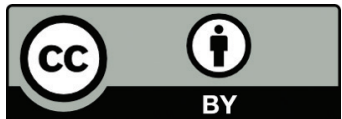

This work is licensed under a Creative Commons Attribution 